\title{
Implementering af e-læring på Det Teologiske Fakultet, Aarhus Universitet
}

\author{
Hans J. Lundager Jensen \\ Professor, dr. theol., studieleder \\ Afdeling for Religionsvidenskab \\ Aarhus Universitet \\ hj@teo.au.dk \\ http://www.teo.au.dk
}

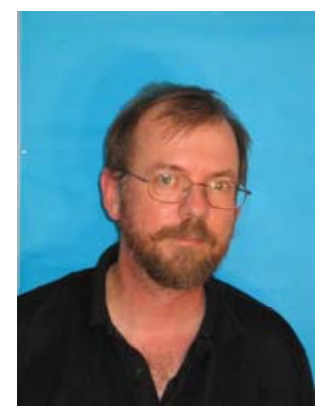

Hans J. Lundager Jensen har veret studieleder for Religionsvidenskab og Arabisk ved Aarhus Universitet siden 2001. I den periode er undervisningskonferenceprogrammet, AULA, blevet indført ved Det Teologiske Fakultet.

\section{Indledning}

E-læring - i betydningen af elektronisk formidlet undervisning eller elektronisk støttet undervisning, jf. definitionen "et middel, som involverer brugen af et eller flere elektroniske redskaber i forskellige sammenhænge" (Brøgger 2003) - blev indført på Det Teologiske Fakultet i 2003. Forud var gået overvejelser på ledelsesniveau om, hvordan e-læring kunne indføres, og forudgående sonderinger med hensyn til valg af bedste system blev drøftet og vurderet. Baggrunden for drøftelserne var bl.a., at fakultetets IKT-ansvarlige havde deltaget i en konference på Aalborg Universitet om fordele og ulemper ved forskellige systemer. Det, der endte med at blive indført, var resultat af et samspil mellem overordnet ledelse, individuelle initiativer og de muligheder, der tilfældigvis forelå på det afgørende tidspunkt. Denne artikel er baseret på forfatterens egen erindring, samtaler med nøglepersoner samt en evalueringsrapport om IKT-støttet undervisning ved Det Teologiske Fakultet ved Morten Hørning Jensen, 2003.

\section{Forberedelsen}

Det Teologiske Fakultet er en relativ lille organisation i universitetssammenhæng. Fakultetet omfatter tre uddannelser: Teologi, Religionsvidenskab samt Arabisk. I 2002 var det klart både for fakultetsledelsen og for mange undervisere, at det var nødvendigt at indføre e-læring $\mathrm{i}$ en eller anden form. Den primære bevæggrund hertil var formentlig, at e-læring blev betragtet som noget, der med nødvendighed ville komme til at høre til en uddannelsesinstitutions redskaber, og som allerede var ved at blive et standardredskab på gymnasier og andre universiteter. Hvilke pædagogisk-didaktiske og administrative muligheder, e-læring ville eller kunne indebære, var på det tidspunkt langt mindre klart. Det afgørende motiv for indføring af elæring var nok mimetisk begrundet, snarere end begrundet $i$ et artikuleret behov, i pædagogisk-didaktiske visioner eller i indsigt $\mathrm{i}$ aktuelle teorier og debatter om læring. Jf. to erhvervslederes dialog i en TV-reklame for IBM fra engang i midten af 1990'erne: "Says here we need to be on the internet" - "Why is that?" - "Doesn't say."

Det Humanistiske Fakultet ved Aarhus Universitet havde anskaffet systemet First Class og var ved at indarbejde det ved bl.a. at afholde møder om muligheder og problemstillinger forbundet med indførelsen af IT-støttet undervisning, og ved at ansætte særligt personale til kurser, tildeling af adgangstilladelse osv. Derimod havde Aarhus Universitet på dette tidspunkt ikke en samlet e-læringsstrategi. Det var derfor fornemmelsen på Det Teologiske Fakultet, at det mere eller mindre var overladt til fakultetet selv at indføre e-læring. 


\section{Det umiddelbare behov}

I foråret 2002 fik Det Teologiske Fakultet overdraget opgaven at forestå undervisningen i faglig supplering for sidefagskandidater i religionsvidenskab, der havde fået ansættelse i gymnasieskolens uddannelsesstillinger. Det var nødvendigt at lade den overvejende del af denne uddannelse foregå som fjernundervisning. Dels krævede bekendtgørelsen om faglig supplering, at en del af undervisningen skulle organiseres som IT-baseret fjernundervisning. Dels var der det praktiske forhold, at deltagerne i og med deres ansættelse ved gymnasier ville være spredt rundt om i landet og kun i begrænset omfang kunne deltage i tilstedeværelsesundervisning. "IT-baseret fjernundervisning" forstod vi sådan, at det måtte implicere anvendelse af et konferenceprogram. Da fakultetet ikke havde et sådant, blev det aftalt med Det Humanistiske Fakultet, at vi i dette tilfælde kunne få lov til at låne os ind på dets First Class; dette "udlån" foregik med stor samarbejdsvilje fra Det Humanistiske Fakultet. I den forbindelse deltog den underviser, der skulle forestå undervisningen i faglig supplering, og en af studielederne i et praktisk kursus om brugen af First Class, som Det Humanistiske Fakultet gennemførte. Studielederen deltog derudover i et antal møder om IT-baseret undervisning, herunder om perspektiverne for overgang fra instruktivistisk til konstruktivistisk læring.

Ledelsen af Det Teologiske Fakultet var betænkelig ved selv at anskaffe First Class, selvom platformen ganske vist havde mange muligheder. På den anden side var en licens bekostelig, og systemet fordrede tilsyneladende en ret besværlig indlæring, tykke instruktionsmapper, kurser, ansættelser og en administration med tildeling af brugernavne og passwords. I november 2002 blev der imidlertid afholdt et orienteringsmøde for hele Aarhus Universitet om e-læring i universitetsundervisning, hvor to af fakultetets medarbejdere, nærmest ved en tilfældighed, deltog. På dette møde blev det dels klart, at Aarhus Universitet var bagefter mange andre universiteter i Europa med hensyn til undervisningskonferenceprogrammer, dels at folk fra Aarhus Universitet kunne foreslå platformen DOKEOS, et gratis open sourceprogram, der var udviklet ved Université Catholique de Louvain. Aarhus Universitet valgte at navngive universitets version af platformen AULA.

\section{AULA}

Det Teologiske Fakultets ledelse besluttede i slutningen af 2002 at forsøge sig med at anvende AULA som fælles platform for al undervisning på fakultetet, og der blev hurtigt oprettet adgang for alle, der ville prøve det. Fakultetets interne IKT-udvalg drøftede på et møde i februar perspektiverne i at bruge AULA, og studielederne for hhv. Teologi og Religionsvidenskab besluttede at forsøge sig med platformen i deres egne undervisningsforløb. Samtidig hermed blev kolleger orienteret på møder og ved personlig coaching om de første skridt ind i AULA.

AULA viste sig at være et særdeles velegnet til en første indføring $i$ at bruge et undervisningskonferenceprogram. Det krævede ikke meget computer-sans at forstå programmet, navigere rundt og gøre brug af dets funktioner, da systemet i mange tilfælde var omtrent selvforklarende og selvindlysende. Det havde tilmed et godt, blødt (og lyseblåt) design. Til gengæld var det tydeligvis i en indledende fase; visse funktioner var på dansk, andre var på engelsk, og universitetets E-læringsenhed havde kun begrænsede ressourcer til at tilpasse og oversætte programmet.

AULA i den første version, som underviserne på Det Teologiske Fakultet mødte, havde et begrænset antal funktioner: En kalender, en dokumentmappe med mulighed for undermapper, en kursusbeskrivelse, en deltagerliste, en mappe med links (med mulighed for undermapper), en meddelelsesmappe med mulighed for e-mails fra underviser til deltagere, en plads for studerendes opgaver, et gruppeforum, en chatfunktion og en funktion, hvor underviseren kunne 
oprette øvelser, hvormed deltageren kunne teste sig selv. Underviseren afgjorde, hvilke af funktionerne der skulle være aktiveret.

Samtidig med at de første undervisere mere eller mindre på egen hånd gik i gang med at bruge AULA til deres individuelle undervisningsforløb, blev ph.d.-studerende Morten Hørning Jensen i februar 2003 ansat i et særligt projekt med henblik på at implementere AULA i fakultetets undervisning fra efterårssemesteret 2003. Projektet omfattede orientering i pædagogisk-didaktiske perspektiver ved brug af IKT i universitetsundervisning, grundig indsigt i muligheder i AULA, afprøvning $i$ et konkret undervisningsforløb samt generel instruktion af fakultetets undervisere i omgangen med programmet.

I løbet af forårssemesteret 2003 blev kendskabet til AULA spredt blandt fakultetets undervisere og studerende ad forskellige kanaler. Morten Hørning Jensen foretog orienteringer af underviserne ved afdelingsmøder, hvor programmets opbygning og muligheder blev demonstreret, og han fungerede desuden som rådgivningsinstans for de undervisere, som allerede var i gang med at anvende AULA. Samtidig spredte kendskabet sig også via kollegial instruktion, hvor kolleger lærte af og rådførte sig med hinanden. I august 2003, forud for begyndelsen på efterårssemesteret, blev der afholdt to kurser for underviserne. Det første kursus angik den mest elementære brug af platformen (tilmelding, e-mailkontakt og brug af funktionerne: Kalender, dokument, link og kursusbeskrivelse). Det andet kursus angik de mere avancerede funktioner (chat, studerendes opgaver, diskussionsforum, øvelser) samt lagde en større vægt på de pædagogiske perspektiver i retning af en større grad af konstruktivistisk læring. Der blev udarbejdet kortfattede instruktionsskrivelser, og til de studerende blev der lagt en tilsvarende kortfattet instruktion ud på fakultetets hjemmeside.

Det teologiske studienævn besluttede desuden på et tidligt tidspunkt at gøre brug af AULAs deltagerregistrering som tilmelding til de enkelte uddannelseselementer, dvs. at benytte platformen som et redskab til uddannelsesadministration, hvad programmet dog ikke egner sig specielt godt til i sin nuværende udgave. Til gengæld bruges AULA til andre administrative funktioner. Det er fx ukompliceret for et studienævn eller et ad-hoc-nedsat udvalg at oprette en konference, samle relevante dokumenter og kommunikere igennem konferencen; på samme måde bruges programmet til tidsskriftsredaktion. Denne brug er opstået spontant. Mig bekendt har ledelsens forestillinger overvejende eller udelukkende angået implementeringen af et undervisningskonferenceprogram og ikke af et system, der også kunne varetage administrative funktioner. Men den del af administrative opgaver, der omfatter lagring af dokumenter og links, en fælles kalender og indbyrdes meddelelser, fungerer bekvemt som en del af AULA.

Fra efteråret 2003 og frem til efteråret 2005 er platformen blevet indarbejdet som en naturlig og ukontroversiel del af undervisningen ved fakultetet, omtrent så triviel som en tavle i et undervisningslokale. En medarbejder ved fakultetssekretariatet varetager praktiske spørgsmål og opretter undervisningsforløbenes konferencer, så de bliver udstyret med de korrekte koder og oplysninger. Derefter udfylder underviserne alle øvrige funktioner. Dette har i øvrigt medført, at oplysningerne i lektionsplanen er blevet betragteligt forkortet. Denne rummer nu kun de mest nødvendige oplysninger om det enkelte undervisningsforløb (om underviser, lokale, tidspunkt, emne angivet i stikord), mens detaljerede oplysninger om forløbets indhold, problematik, litteraturliste osv. er lagt ud i forløbets konference.

Det er så ganske vist de mindst avancerede funktioner, der hyppigst bliver anvendt, $\mathrm{i}$ hvert fald når AULA fungerer som støtte for den daglige tilstedeværelsesundervisning. Mere intensiv brug, der nærmer sig e-læring i snævrere forstand, sker i forbindelse med den omtalte sidefagssupplering; men den fylder kvantitativt lidt i fakultetets samlede undervisning. Der har endnu ikke været konkrete overvejelser i gang på fakultetet i retning af at følge op på de 
teknologiske muligheder, som konferenceprogrammet også indebærer. Man kunne fx omlægge en del af den normale undervisning fra tilstedeværelsesundervisning til e-læring eller forlægge en del af undervisertiden fra tilstedeværelsesundervisning til tid foran skærmen ved chatfunktionen eller lignende. E-læringen er kommet til at fungere som en udvidelse af den traditionelle tilstedeværelsesundervisning: Underviseren eller institutionen fritages for megen kopiering, opslag på opslagstavler og døre om aflysninger og ændringer af undervisningstidspunkter og -steder osv. Linkfunktionen gør naturligvis henvisninger til internetsider langt mere effektive og fremmer uden tvivl de studerendes brug af internettet som en art leksikon (fx Wikipedia). Det er muligt, at evalueringsfunktionen i AULA vil få en større anvendelse i de kommende år.

Der har i øvrigt heller ikke, indtil videre i hvert fald, hverken blandt de studerende eller blandt underviserne været nogen markant interesse for en omlægning af undervisningen i de første studieår fra instruktivistisk til konstruktivistisk læring. På den måde kan indførelsen af et konferenceprogram måske ses som et eksempel på en mere generel tendens, kendt fra videooptagere og mobiltelefoner: En ny teknologi kan ofte mere, end de fleste brugere orker at sætte sig ind i og udnytte.

\section{Konklusion}

Indførelsen af e-læring på Det Teologiske Fakultet er sket uden nærmere formulerede pædagogisk-didaktiske visioner; vi har fået et ikke specielt avanceret redskab stillet til rådighed, som til gengæld, næsten uden instruktion, har kunnet tages i anvendelse af alle. Selve indførelsen har været en proces, der har kombineret femårsplan og kaos. På den ene side har indførelsen betydet ledelsesstrategi og -beslutninger "fra oven", indførelsen af en platform, valg af AULA, ansættelse af medarbejder i en kortere perioder, systematisk orientering af undervisere samt kortere instruktionskurser. På den anden side har indførelsen betydet initiativer "nedenfra": Opmærksomhed på AULA, spontan anvendelse i undervisningsforløb uden forudgående plan og spontan, kollegial instruktion.

\section{Litteratur}

Brøgger, Øjvind. E-læring, en pæedagogisk mulighed, UNI-C, 2. juli 2003. Online: $<$ http://design.emu.dk/artik/03/27-elearning.html > (set 01.11.2005).

Jensen, Morten Hørning. Projekt IKT-støttet undervisning. Evalueringsrapport. Århus: Det Teologiske Fakultet, Århus Universitet, 2003 